\title{
A Review of Research Progress of Pregnancy with Twins with Preeclampsia
}

\author{
Ying Wang' \\ $\mathrm{Na} \mathrm{Wu}{ }^{2}$ \\ Haitao Shen (iD ${ }^{3}$ \\ 'Department of Obstetrics and \\ Gynecology, Shengjing Hospital of China \\ Medical University, Shenyang, I I0004, \\ People's Republic of China; ${ }^{2}$ Department \\ of Endocrinology, Shengjing Hospital of \\ China Medical University, Shenyang, \\ I I0004, People's Republic of China; \\ ${ }^{3}$ Department of Emergency Medicine, \\ Shengjing Hospital of China Medical \\ University, Shenyang, I I0004, People's \\ Republic of China
}

\begin{abstract}
Preeclampsia has a significant long-term effect on the health of both mothers and babies. Preeclampsia-related pregnancy complications increase the morbidity and mortality of pregnant women and their fetuses by $5-8 \%$. The recent advancement of assisted reproductive technology, combined with a rise in the number of elderly pregnant women, has resulted in pregnancy incidence with twins. Twins pregnant women have a 2-3 times greater risk of developing preeclampsia than singleton pregnant women, and it happens sooner and progresses faster. It is more severe and may appear in an atypical way. End-organ damage, such as renal failure, stroke, cardiac arrest, pulmonary edema, placental abruption, and cesarean section, are related maternal complications. Fetal growth retardation, stillbirth, and premature delivery with obstetric signs are all fetal complications. According to studies, all multiple pregnancies can take low-dose aspirin $(60-150 \mathrm{mg})$ to minimize the risk of preeclampsia. To improve pregnancy outcomes and reduce the inherent risk of pregnancy with twins, twins should be handled as a high-risk pregnancy and treated differently than singletons. The literature on twin pregnancy with preeclampsia is the subject of this review. It will examine the current state of research on preeclampsia in pregnancy with twins, including the occurrence, diagnosis, and pathophysiological process. Moreover, the effect of pregnancy with twins on the perinatal outcome and pregnancy management of pregnancy with twins, including blood pressure management and preeclampsia prevention and treatment, is examined in this literature review. The goal is to figure out what kind of diagnosis and care you may need.
\end{abstract}

Keywords: twins, pregnancy, preeclampsia

\section{Introduction}

With the implementation of China's "two child" policy, the incidence of multiple pregnancies, especially twins, is growing year after year. Multiple pregnancies become more common as assisted reproductive technology becomes more widely used and the increasing age of conception rises. ${ }^{1}$ On the other hand, women with multiple pregnancies have a higher rate of pregnancy complications, fetal malformations, perinatal morbidity, and mortality than women with single pregnancies, which has become a challenging issue in maternal and fetal medicine. Preeclampsia is 2-3 times more common in twin pregnancies than in singleton pregnancies, and it develops sooner, progresses quicker, and is more severe, as well as presenting in an atypical manner. $^{2}$ The incidence rate of maternal diseases, including terminal organs such as cardiac arrest, stroke, renal failure, lung injury, and others, are more likely to cause placental abruption and pathological cesarean section. ${ }^{3}$ Fetal growth restriction, stillbirth, and premature delivery are all examples of fetal
Correspondence: Haitao Shen

Tel +86-18940256180

Email pianzhang6@I63.com 
complications. Given the preceding evidence, preeclampsia literature focusing on multiple pregnancies is relatively scarce. Our goal is to review the literature on Preeclampsia in twin pregnancy, find out the gap in evidence, and comprehensively understand the pathophysiology of Preeclampsia in twin pregnancy. We must fully comprehend the physiology of twins as well as the pathophysiology of Preeclampsia. The aim is to increase the birth population's efficiency, customized twin pregnancy management, pay attention to early pregnancy, and do a good job in twin pregnancy management to find out the potential diagnosis and care in the future. It is important to reduce the global prevalence of perinatal outcomes, morbidity, and mortality among women.

\section{The Incidence of Preeclampsia in Pregnancy with Twins}

In recent years, there has been widespread use of assisted reproductive technology, owing primarily to a rise in the number of elderly women. As a result, the number of twin pregnancies is growing on an annual basis. Preeclampsia, gestational diabetes mellitus, premature birth, fetal growth restriction, pathological surgical delivery, and other perinatal complications are more common in women with twin pregnancies when compared to singletons. ${ }^{4}$ According to the literature, Preeclampsia accounts for $2-5 \%$ of pregnancy complications. Preeclampsia is described as an increase in blood pressure and proteinuria after 20 weeks of gestation. ${ }^{5}$ Preeclampsia symptoms include headache, dizziness, nausea, vomiting, epigastric discomfort, and others. Preeclampsia progresses to the more severe condition known as eclampsia. Eclampsia is a convulsion or coma that cannot be explained by other causes other than Preeclampsia. The etiology is yet to be determined. Eclampsia is a severe complication of Preeclampsia that may cause significant maternal and neonatal complications. Currently, there is no effective preventive treatment except the termination of pregnancy. The existing therapy aims to control the disease and extend the gestational period. According to reports, Preeclampsia is responsible for about $14 \%$ of maternal deaths. ${ }^{6}$ Preeclampsia is thought to be associated with long-term cardiovascular disease, ${ }^{7}$ particularly in early-onset Preeclampsia and recurrent Preeclampsia, increasing cardiovascular disease risk. $^{8-10}$ Preeclampsia is currently classified into earlyonset and late-onset Preeclampsia based on the 34-week gestation period. Early-onset preeclampsia is characterized by small gestational weeks, long distance from full-term, and maternal and neonatal complications. ${ }^{11}$ However, early-onset and late onset have different occurrence rates, clinical manifestations, and risk factors. Early-onset Preeclampsia is thought to be linked to the likelihood of fetal intrauterine growth restriction, resulting in extreme vascular endothelial damage. In contrast, late-onset Preeclampsia is linked to maternal weight gain and neonatal weight gain. ${ }^{12-14}$ Multiple pregnancies are an independent risk factor for Preeclampsia. ${ }^{15,16}$

Preeclampsia was slightly more common in twin pregnancies than in singleton pregnancies. Preeclampsia was 3.50 times higher in dizygotic twins than in monozygotic twins and 2.61 times higher in monozygotic twins. Furthermore, twins are two to three times more likely than singletons to develop extreme hypertension. ${ }^{17}$ Preeclampsia occurs at an earlier gestational age in twin pregnancies, and the incidence is substantially higher than in singleton pregnancies. ${ }^{18}$ There is a clear connection between adverse pregnancy outcomes and twin pregnancies; ${ }^{19}$ it may be because twin pregnancies have a larger placental size, exposing the maternal to a larger area of placental perfusion damage. ${ }^{15}$ The overall peripheral resistance of the uterus and placenta increases as the twins develop. The placenta's angiogenic factors may harm the functionality of the vascular endothelium in the dynamic process. ${ }^{20}$ The incidence of Preeclampsia is significantly higher in triplets ${ }^{20}$ than that of triplets experiencing reduction. ${ }^{21}$ These findings further confirm the pathogenicity of placental tissue. ${ }^{22}$ Preeclampsia is also more common in IVF twins than in naturally born twins, according to research. Preeclampsia increases the risk of preterm birth, surgical delivery, and low birth weight in invitro twins. ${ }^{23}$ Studies have shown that, as opposed to fresh embryos, frozen embryo transfer increases the risk of preeclampsia and preterm delivery in pregnancies with assisted reproductive technology that uses autologous eggs. $^{24}$

\section{Diagnosis and Pathophysiology of Preeclampsia in Pregnancy with Twins}

Preeclampsia in twin pregnancies and singleton pregnancies is currently diagnosed using the same diagnostic criteria. The following is the current definition of Preeclampsia: after 20 weeks of pregnancy, systolic blood pressure and diastolic blood pressure increase to $\geq$ $140 \mathrm{mmHg}$ and $\geq 90 \mathrm{mmHg}$ respectively, on two or more 
consecutive occasions (interval $\geq 4 \mathrm{~h}$ ), and when the patient's blood pressure is elevated and one or more of the following abnormalities occur at the same time:(1) Proteinuria (24-hour urine total protein content $\geq 300 \mathrm{mg}$ or $\geq 1+$ ); (2) Dysfunction of important organs of the mother's body, such as abnormal renal function (creatinine $<90 \mathrm{umol} / \mathrm{L}$ ), liver damage (elevated transaminase or epigastric discomfort), neurological and hematological abnormalities. $^{25}$ This study aims to conduct a literature review on Preeclampsia, with a focus on twin pregnancies. The aim is to identify evidence gaps that can direct potential diagnosis and care of twin pregnancies. As a result, it is important to better understand the pathophysiology of Preeclampsia in twin pregnancies. ${ }^{6}$ Although most pathophysiological studies on Preeclampsia have been conducted in singleton pregnancy, their effect would be amplified in pregnancy with twins due to greater placental mass and stronger inflammatory response. According to research, the possibility of Preeclampsia is a dosedependent condition that is greatly influenced by the quality of the placenta and the number of fetuses. ${ }^{23}$

The abnormal condition of elderly women, obesity, diabetes, chronic hypertension, antiphospholipid syndrome, chronic kidney disease, and lupus erythematosus all raise the risk of Preeclampsia. Endothelial dysfunction has been recorded in these cases, increasing the risk of Preeclampsia. ${ }^{26}$ In previous studies, excessive placental anti-angiogenic factors and soluble FMS including tyrosine kinase 1 (sflt1), were found to antagonize vascular growth factor (VEGF) and placental growth factor (PlGF), causing extensive endothelial dysfunction in these women. $^{20,27-29}$ The single nucleotide polymorphism (rs4769613) near the Flt1 site on fetal chromosome 13 was found to be significantly associated with Preeclampsia in a large clinical genome-wide association study. $^{30,31}$ The amount of Flt1 in the blood of pregnant women with chronic hypertension and diabetes mellitus increased significantly.

Meanwhile, PLGF levels in the blood of obese pregnant women were found to be substantially lower. ${ }^{32}$ The mechanism of Flt1 upregulation in the placenta is still unknown. Flt1 precursor mRNA produced sflt1 after alternative splicing and only contained the Flt1 extracellular ligand binding region. It does not, however, produce intracellular or transmembrane regions. ${ }^{33}$ Increased placental mass and circulating levels and soluble FMS like tyrosine kinase-1 can increase the risk of Preeclampsia in multiple pregnancies (sFlt-1).
Endothelial dysfunction may lead to a vascular condition that affects the entire body. The widespread use of assisted reproductive technology has increased the number of elderly twin births, which has increased in maternal primary diseases. Endothelial dysfunction can result from increased cardiac output and systemic total peripheral resistance in chronic hypertension patients. ${ }^{34}$ Sympathetic neuropathy is caused by insulin resistance and a high insulin level. Endothelial cell damage from abnormal renal tubular sodium absorption will increase the risk of Preeclampsia. ${ }^{34}$ In the first three months of pregnancy, a lack of trophoblast penetration and inadequate remodeling of the uterine spiral artery, combined with decreased uterine placental perfusion, may result in poor perfusion and stress of placental syncytiotrophoblast cells, which releases a series of mediators that cause endothelial dysfunction and clinical manifestations. ${ }^{35}$ It is true that the exact mechanism by which endothelial dysfunction leads to systemic vascular disease is unknown. Insufficient vascular remodeling, which is the secret to systemic vascular dysfunction, may be caused by irregular matrix metalloproteinases (MMPs) and increased extracellular collagen deposition. ${ }^{36}$ Vascular instability persists after preeclampsia symptoms have vanished clinically, suggesting that it may be linked to long-term cardiovascular disease risk.

A growing number of studies have looked into the connection between immune abnormalities and Preeclampsia in recent years. The expression of the histocompatibility complex is one of the most important factors (MHC). HLA-C molecules expressed in trophoblast interact with killer Ig like receptors (KIR) expressed by maternal natural killer cells in normal pregnancy. Normal placenta formation necessitates maternal KIR to recognize allogeneically HLA-C of the father. ${ }^{37}$ According to the findings, some HLA-C molecular groups' expression frequency and some KIR haplotypes appears to be higher in preeclampsia patients. ${ }^{38}$ Preeclampsia risk rises as the father's antigen exposure decreases, as in the case of nulliparous women, short-term cohabitation, and paternity, ${ }^{39}$ indicating the role of the immune system in pathogenesis. ${ }^{39,40}$ Placental tissue has the characteristics of secreting T cells and some other cytokines, of which type 2 helper $\mathrm{T}$ cell factor (such as anti-inflammatory IL-10) is the main factor. ${ }^{41}$ An unbalanced $\mathrm{T}$ cells' distribution distinguishes Preeclampsia, especially T helper cell 1 and its associated cytokines IFN and TNF. ${ }^{42}$ This immune factor imbalance can result in fetal adnexal dysplasia, followed by maternal inflammation and endothelial dysfunction. Complement activation, on the other hand, is 
linked to the pathogenesis of Preeclampsia. ${ }^{43,44}$ The complement-activated fragment $\mathrm{BB}$, a marker of alternative pathways, was measured by the researchers and found that women with higher BB levels were four times more likely to develop Preeclampsia before 20 weeks of gestation. All of this suggests that complement activation plays a role in the onset and development of Preeclampsia. ${ }^{45}$ In animal models, angiogenic factor imbalance appears to occur before complement activation. ${ }^{46}$ Complement activation could play a larger role in the development of Preeclampsia. ${ }^{47}$ Formalized paraphrase According to some studies, atypical hemolytic uremic syndrome (aHUS) with excessive activation of the complement replacement pathway is similar to severe preeclampsia syndrome (HELLP syndrome). ${ }^{47,48}$ Inhibiting complement activation has been shown in studies to prevent the increase of sflt1 in pregnant mice. ${ }^{49}$ If this hypothesis is confirmed in twins, dichorionic twins with high placental immunogenicity have a higher risk of Preeclampsia than monozygotic twins. However, the available data do not appear to support the increased risk of Preeclampsia in twins. $^{50}$

Presently, the ratio of Preeclampsia increased to 1.65 for women with a body mass index between $25 \mathrm{~kg} / \mathrm{m} 2$ and $30 \mathrm{~kg} / \mathrm{m} 2$, and 6.04 for women with body mass index $\geq$ $40 \mathrm{~kg} / \mathrm{m} 2$. The precise underlying mechanism is uncertain. ${ }^{51}$
At the moment, the impact of genetic factors on the onset of Preeclampsia is also worth considering. The risk of Preeclampsia in nulliparous mothers or sisters with a preeclampsia family history is 2 to 5 times higher than in nulliparous mothers without a preeclampsia family history. A study of preeclampsia sisters revealed that the fetal inheritance of the mother's stox 1 missense mutation at 10q22 resulted in the development of Preeclampsia. Paternal homologous gene inheritance, on the other hand, does not result in Preeclampsia during pregnancy. Preeclampsia is more likely in mothers who have a trisomy 13 fetus. According to research, the sFlt-1 and Flt-1 genes linked to Preeclampsia, are also found on chromosome $13 .^{3}$ (Figure 1)

Despite these well-known facts, the literature on multiple pregnancies in Preeclampsia is limited when compared to singleton pregnancies. Women who have multiple pregnancies are typically excluded from studies or included in undifferentiated singleton studies. The focus of these patients has created new challenges. It is critical to include this population in future research in order to improve perinatal outcomes and reduce the incidence rate and mortality of women worldwide. These women are known to be at a higher risk of many obstetric complications, particularly Preeclampsia. Furthermore, their pregnancy process differs from that of singletons. Based on evidence of

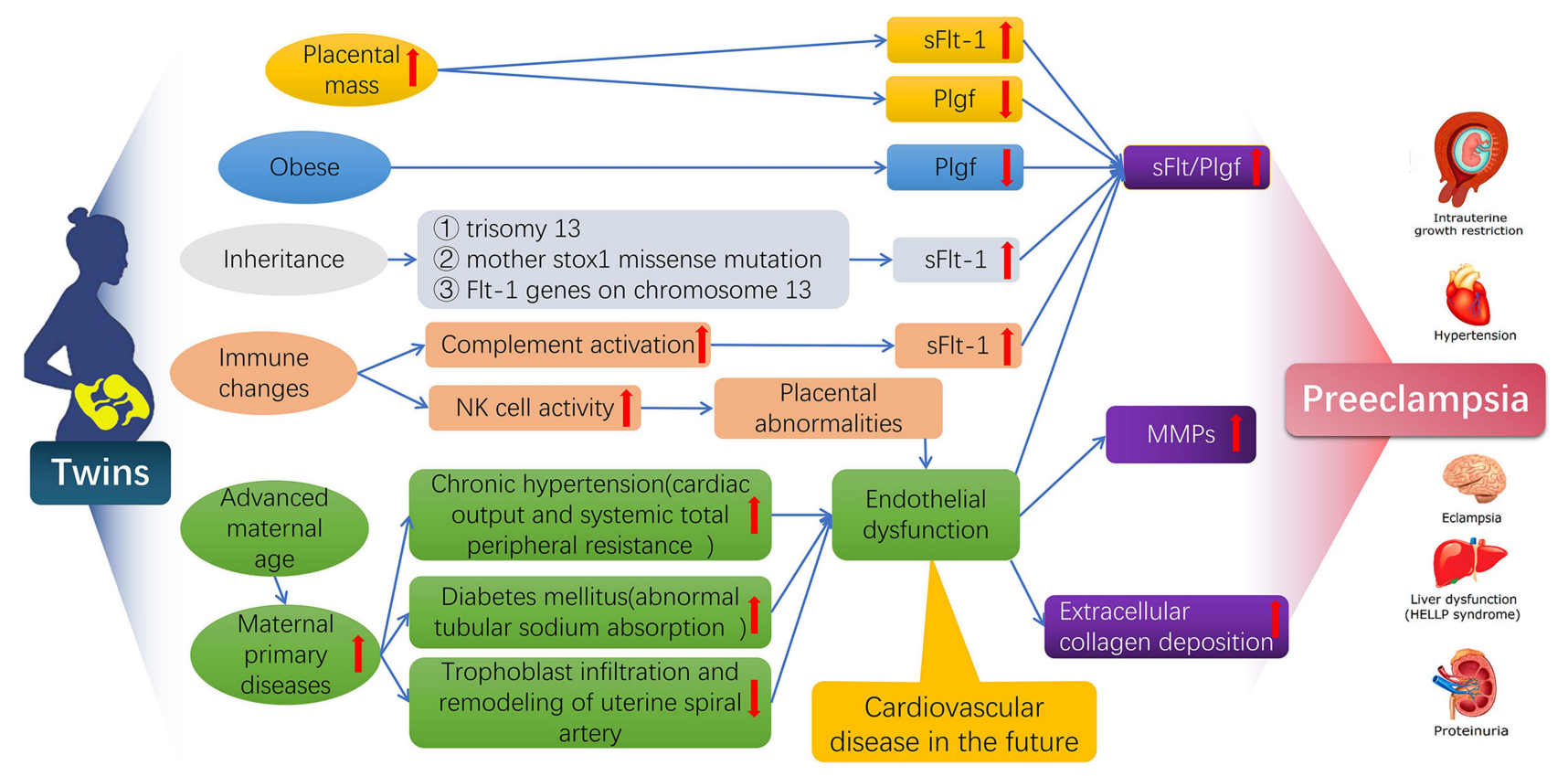

Figure I The pathogenesis of twin preeclampsia, from the characteristics of twin, twin placenta area is larger, produce more anti angiogenic substances, assisted reproductive technology is widely used, old age, obesity and maternal primary disease increase, immune disorders, the role of genetic factors, from many aspects reveals the mechanism of the occurrence and development of twin preeclampsia.

Abbreviations: MMPs, matrix metalloproteinases; sflt I, soluble FMS like tyrosine kinase I; PIGF, placental growth factor. 
multiple births, it is more appropriate to investigate specific guidelines and pathophysiological processes.

\section{Influence of Preeclampsia on Perinatal Outcome of Twins Pregnant Women}

One of the most common pregnancy complications is Preeclampsia. It has far-reaching consequences for mothers' and infants' short- and long-term health, including maternal organ dysfunction, which includes renal failure, liver involvement, neurological or hematological complications, uterine placental dysfunction, and fetal growth restriction. ${ }^{5}$ Preeclampsia is a common cause of maternal and fetal death and morbidity around the world. ${ }^{52}$ Many identified risk factors are thought to be linked to the etiology of Preeclampsia, but the specific etiology remains unknown. Preeclampsia is more common in older women, obese mothers, diabetic mothers, and mothers with prepregnancy hypertension. Preeclampsia is also linked to the mother's and offspring's long-term cardiovascular disease development. ${ }^{7}$ Preeclampsia significantly increased the risk of adverse pregnancy outcomes in the offspring, including cesarean section, placental abruption, SGA, preterm birth, and 5-minute Apgar score $<7$. Furthermore, numerous studies have found a link between an adverse intrauterine environment for the fetus and adult diseases like coronary atherosclerotic heart disease, hypertension, obesity, type 2 diabetes, and so on. ${ }^{53}$ The level of understanding and management of Preeclampsia has improved as current research on the disease progresses. Previously, most research focused on singleton pregnancies. Only a few studies, particularly those with a higher level of evidence on Preeclampsia's long-term effect on the offspring of twin pregnancies, have looked into the link between twin pregnancies and Preeclampsia.

The findings of various studies on the impact of Preeclampsia on twin pregnancies' perinatal outcomes are neither conclusive nor consistent. Common risk factors such as maternal age, parity, body mass index (BMI), diabetes, smoking, socioeconomic status (education level is an indicator), and in vitro fertilization (IVF) were evaluated by Laine et $\mathrm{al}^{54}$ in a statistical analysis of women who gave birth in Norway from 1999 to 2014. The findings showed that the risk of Preeclampsia in twin pregnancies was higher than previously thought, and that the prevalence of Preeclampsia in twin pregnancies was three to four times that of singleton pregnancies. Sibai et $\mathrm{al}^{55}$ discovered a trend that complemented Laine's findings.
However, the risk of Preeclampsia from twin pregnancies was estimated to be lower than in Laine's study (AOR $2.48,95 \%$ CI 1.82 to 3.38 ). Only 8 out of 92 articles in another large meta-analysis listed multiple births as a risk factor for Preeclampsia, confirming the lack of research into the relationship between twin pregnancies and Preeclampsia. ${ }^{56}$

The study discovered that the risk of hypertension in twins increased following natural pregnancy or assisted reproductive technology, but after assisted reproductive technology pregnancy (risk difference, 1.73 percentage points every five years; confidence interval, 95\%, 1.35-2.11 percentage points every five years) was higher than that in twins after natural pregnancy (risk difference, 0.75 percentage points; confidence interval, 95\%, 1.35-2.11 percentage points every five years); The confidence interval was $95 \%, 0.61-0.89$ percentage points every five years). ${ }^{57}$ Twin pregnancy has more severe Preeclampsia. ${ }^{58}$

When chorionic factors of twins are considered, some studies have found that women with dizygotic chorionic twins (DC) have an increased risk of Preeclampsia compared to monozygotic ones chorionic twins (MC). Bartnik et al looked at 233 dizygotic chorionic twins (DC) and 79 monozygotic chorionic twins (MC) twins. It was discovered that the risk of Preeclampsia was three to four times higher in dizygotic chorionic twins (DC) pregnancy. ${ }^{59}$ Sparks et al discovered that the risk of Preeclampsia doubled in women carrying dizygotic chorionic twins. ${ }^{60}$ However, Savvidou et al discovered no difference in preeclampsia risk between monozygotic and dizygotic chorionic twins. ${ }^{61}$ The risk of preterm $\mathrm{PE}$ in $\mathrm{DC}$ and $\mathrm{MC}$ twins is comparable to and significantly higher than in singleton pregnancies. ${ }^{18} \mathrm{GDM}$ has a greater influence on MCDA twin pregnancy, manifested as maternal hypertensive disorder complicating pregnancy and SGA. ${ }^{62}$ In the twins with Preeclampsia, map (mean arterial pressure) was significantly higher than that in the twins without Preeclampsia ( $\mathrm{P}<0.02$, one tailed), while the level of Doppler PI (Doppler pulse index) was significantly lower. $\left(\mathrm{P}<0.01\right.$, two-tailed). ${ }^{63}$ Twin pregnancy had a lower mid-term Doppler PI level than singleton pregnancy ${ }^{64}$ The study found no difference in the incidence of hypertension during pregnancy between women with and without gestational diabetes after adjusting for mother's age, in vitro fertilization treatment, race, and prepregnancy body mass index ${ }^{65}$ The incidence of hypertensive disorders complicating pregnancy (Preeclampsia and gestational hypertension) was comparable between the two groups, but the incidence of severe Preeclampsia was higher 
in twin pregnancy ( 8 cases $(5.9 \%)$ than in twin pregnancy $(0$ case, $\mathrm{P}=0.057)^{66}$ Compared with preeclampsia singletons, twins had higher mean birth weight, lower small for gestational age (SGA) and fewer births $<34$ weeks and $<32$ weeks. The incidences of placental weight $<10 \%$ (AOR 0.49 , 95\% CI 0.33-0.71), fetal vascular pathology (AOR 0.28 , 95\% CI 0.20-0.39) and fetal vascular perfusion pathology (AOR 0.65, 95\% CI 0.45-0.93) was significantly reduced. The findings support the hypothesis that MVM has little to do with the pathogenesis of HDP in twin pregnancy, and that other placental or non-placental factors are to blame for the increased risk. ${ }^{67}$ In terms of perinatal mortality, there was no difference. ${ }^{68}$ The risk of PE was higher in twin pregnancies with chronic hypertension than in singleton pregnancies $(\mathrm{P}<0.01)$. The risk of $\mathrm{PE}$ was higher in twin pregnancies with chronic hypertension than in singleton pregnancies $(\mathrm{P}<0.01)$. The gestational age of twin pregnancy with $\mathrm{PE}$ was earlier $(\mathrm{P}<0.001)$, and SGA was more. ${ }^{69}$ When comparing mothers and neonates of twin pregnancies complicated to mothers and neonates of singleton pregnancies complicated by severe Preeclampsia, there does not appear to be a difference in morbidity and mortality. $^{70}$ (Table 1)

Because the burden associated with multiple pregnancies increases, the increased risk of Preeclampsia in twin pregnancies could be due to different pathophysiological progress. It differs from other risk factors that may remain unchanged during pregnancy as the pregnancy progresses. Preeclampsia may be caused by an oversized placental volume or an insufficient placental blood supply. ${ }^{71}$ The total peripheral resistance of the uterus and placenta increases as the twins grow, and the angiogenic factors released by the placenta may harm vascular endothelial function in the dynamic process. ${ }^{20}$

\section{Preeclampsia Management During a Twin Pregnancy}

Preeclampsia patients can improve their perinatal outcomes by managing their pregnancies. Previous studies only looked at singleton pregnancies or only included a small number of twin pregnancies, so preeclampsia patients with twin pregnancies have no way of knowing what kind of pregnancy management they should expect. The primary advice is to prevent Preeclampsia. Antiplatelet drugs, particularly aspirin, are effective and safe in preventing Preeclampsia in women at moderate or high risk in at least 75 randomized controlled trials. ${ }^{72,73}$
According to meta-analyses, women at high risk of Preeclampsia who started taking aspirin between 12 and 16 weeks of pregnancy had a 53\% lower relative risk of pregnancy (95\% confidence interval: $35 \%$ to $66 \%)^{74-76}$

In the United States, the Society of Obstetricians and Gynecologists recommends that women with a history of recurrent Preeclampsia or severe illness requiring delivery use low-dose aspirin as a preventive measure 34 weeks prior. ${ }^{5}$ However, such stringent precautions have little effect on the overall health consequences of Preeclampsia. Moreover, public health publications have recommended low-dose aspirin prophylaxis for all women with twins pregnancies. ${ }^{5,77}$ As a result, the potential benefits of low-dose aspirin for women with twin pregnancies must be emphasized. Low-dose aspirin has been shown to prevent Preeclampsia's onset and progression by promoting the invasion and migration of trophoblast cells into the uterine artery, interfering with cytokine production and promoting the production of the angiogenic protein placental growth factor (PlGF). As a result, inhibition of apoptosis and early uterine artery remodeling may help to prevent the onset and progression of Preeclampsia. ${ }^{78}$

When comparing twins and singletons, it was discovered that a high carbohydrate diet combined with a lack of protein, iron, and other micronutrients can cause preeclampsia. $^{79}$ To further optimize pregnant mothers and children's health, it is critical to determine the appropriate maternal nutrition or micronutrient supplement.

Analysis of maternal characteristics, maternal mean arterial pressure, uterine artery pulsatility index, and serum biochemical indicators are currently the most commonly used screening methods for early detection of Preeclampsia (PAPP-A and/or PlGF), which can be measured as early as 11-13 weeks of gestation. The severity of maternal antiangiogenesis in preeclampsia patients in the third trimester of pregnancy may be more accurate than elevated blood pressure in predicting the occurrence of preeclampsia complications. ${ }^{80,81}$ In pregnant women with Preeclampsia within 34 weeks, the sFlt-1/PlGF ratio was 85 , which could predict premature delivery within two weeks, and the risk ratio was 15.2. ${ }^{80}$ The sFlt-1/PlGF ratio $<38$ had a high negative predictive value $(99.3 \%)$ for complications within 1 week. ${ }^{82}$ Furthermore, other research has found that patients with Preeclampsia but normal angiogenesis have no adverse maternal or neonatal complications. ${ }^{83}$ Regardless of the development of Preeclampsia, the remaining delivery time of patients with sflt1/PlGF 
Table I Summary of Studies on the Clinical Features of Twins

\begin{tabular}{|c|c|c|c|c|c|c|}
\hline Author & Country & Year & $\begin{array}{l}\text { Experimental } \\
\text { Model }\end{array}$ & Outcome & Result & Ref. \\
\hline Svirsky & Israel & 2014 & $\begin{array}{l}147 \text { twins and I } 10 \\
\text { singleton }\end{array}$ & MAP and PI Variability & $\begin{array}{l}\text { In the twins with preeclampsia, map (mean } \\
\text { arterial pressure) was significantly higher than } \\
\text { that in the twins without preeclampsia ( } P< \\
0.02 \text {, one tailed), while the level of Doppler PI } \\
\text { (Doppler pulse index) was significantly lower. } \\
(\mathrm{P}<0.01 \text {, two tailed) }\end{array}$ & [50] \\
\hline Chen & Japan & 1998 & $\begin{array}{l}24 \text { twins and } 99 \\
\text { singleton }\end{array}$ & PI Variability & $\begin{array}{l}\text { The mid-term Doppler PI level of twin pregnancy } \\
\text { was lower than that of singleton pregnancy }\end{array}$ & [5। \\
\hline Mourad & USA & 2021 & 614 twins & $\begin{array}{l}\text { The rate of hypertensive } \\
\text { disorders of pregnancy in the } \\
\text { GDM group }\end{array}$ & $\begin{array}{l}\text { After adjusting for mother's age, in vitro } \\
\text { fertilization treatment, race and pre pregnancy } \\
\text { body mass index, the study found that there } \\
\text { was no difference in the incidence of } \\
\text { hypertension during pregnancy between } \\
\text { women with and without gestational diabetes }\end{array}$ & [52] \\
\hline Mor & Israel & 2020 & $\begin{array}{l}\text { I } 35 \text { twins and } 63 \\
\text { singleton }\end{array}$ & $\begin{array}{l}\text { The rate of gestational } \\
\text { hypertensive disorders } \\
\text { (preeclampsia and gestational } \\
\text { hypertension) }\end{array}$ & $\begin{array}{l}\text { Compared with twin pregnancy, the incidence of } \\
\text { hypertensive disorder complicating pregnancy } \\
\text { (preeclampsia and gestational hypertension) was } \\
\text { similar, but the rates of severe preeclampsia } \\
\text { trended higher In twins }(8(5.9 \%) \text { vs } 0, p=0.057) \text {. }\end{array}$ & [53] \\
\hline Petersen & Norway & 2020 & $\begin{array}{l}125,708 \text { singleton, } \\
20,668 \text { twins }\end{array}$ & $\begin{array}{l}\text { The rate of gestational } \\
\text { hypertensive disorders }\end{array}$ & $\begin{array}{l}\text { The study found that the risk of hypertension in } \\
\text { twins after natural pregnancy or assisted } \\
\text { reproductive technology was increased, but } \\
\text { after assisted reproductive technology } \\
\text { pregnancy (risk difference, I. } 73 \text { percentage } \\
\text { points every } 5 \text { years; confidence interval, } 95 \% \text {, } \\
\text { I.35-2.II percentage points every } 5 \text { years) was } \\
\text { higher than that in twins after natural } \\
\text { pregnancy (risk difference, } 0.75 \text { percentage } \\
\text { points; confidence interval, } 95 \% \text {, } \\
\text { I.35-2.II percentage points every } 5 \text { years); } \\
\text { The confidence interval was } 95 \% \text {, } \\
0.61-0.89 \text { percentage points every five years) }\end{array}$ & [45] \\
\hline Aviram & Canada & 2018 & $\begin{array}{l}\text { I } 44 \text { twins and } 768 \\
\text { singleton }\end{array}$ & $\begin{array}{l}\text { SGA (small for gestational age) } \\
\text { and maternal vascular } \\
\text { malperfusion (MVM) }\end{array}$ & $\begin{array}{l}\text { Compared with preeclampsia singletons, twins } \\
\text { had higher mean birth weight, lower small for } \\
\text { gestational age (SGA) and fewer births }<34 \\
\text { weeks and }<32 \text { weeks. The incidences of } \\
\text { placental weight }<10 \% \text { (AOR } 0.49,95 \% \mathrm{Cl} \\
0.33-0.7 \text { ), fetal vascular pathology (AOR } 0.28 \text {, } \\
95 \% \mathrm{Cl} 0.20-0.39 \text { ) and fetal vascular perfusion } \\
\text { pathology (AOR } 0.65,95 \% \mathrm{Cl} 0.45-0.93 \text { ) were } \\
\text { lower. The results support the hypothesis that } \\
\text { MVM has little relationship with the pathogenesis } \\
\text { of HDP in twin pregnancy, and suggest that other } \\
\text { placental or non placental factors are the reasons } \\
\text { for the increased risk in twin pregnancy }\end{array}$ & [54] \\
\hline
\end{tabular}

(Continued) 
Table I (Continued).

\begin{tabular}{|c|c|c|c|c|c|c|}
\hline Author & Country & Year & $\begin{array}{l}\text { Experimental } \\
\text { Model }\end{array}$ & Outcome & Result & Ref \\
\hline Francisco & UK & 2017 & $\begin{array}{l}93,297 \text { singleton, } \\
\text { I } 789 \mathrm{DC} \text { twin and } \\
\text { in } 430 \mathrm{MC} \text { twin }\end{array}$ & The relative risk of preterm PE & $\begin{array}{l}\text { The relative risk of pre term } \mathrm{PE} \text { in } \mathrm{DC} \text { and } \mathrm{MC} \\
\text { twins is similar and substantially higher than in } \\
\text { singleton pregnancies }\end{array}$ & {$[\mathrm{II}]$} \\
\hline Henry & USA & 2013 & 3244 twins & The rates of severe preeclampsia & $\begin{array}{l}\text { The severity of preeclampsia in twin pregnancy } \\
\text { was higher than that in singleton pregnancy }\end{array}$ & [46] \\
\hline Foo & Australia & 2012 & $\begin{array}{l}3942 \text { singleton } \\
\text { and } 214 \text { twins }\end{array}$ & SGA, The rates of preeclampsia & There was no difference in perinatal mortality & [55] \\
\hline Hiersch & China & 2019 & 333 twins & SGA, The rates of preeclampsia & $\begin{array}{l}\text { GDM has a greater impact on MCDA twin } \\
\text { pregnancy, manifested as maternal hypertensive } \\
\text { disorder complicating pregnancy and SGA }\end{array}$ & [49] \\
\hline Connolly & USA & 2016 & $\begin{array}{l}63 \text { twin and } 339 \\
\text { singleton }\end{array}$ & $\begin{array}{l}\text { Morbidity and mortality by } \\
\text { severe preeclampsia. }\end{array}$ & $\begin{array}{l}\text { Mothers and neonates of twin pregnancies } \\
\text { complicated by preeclampsia do not appear to } \\
\text { have greater morbidity and mortality compared } \\
\text { to mothers and neonates of singleton } \\
\text { pregnancies. }\end{array}$ & [57] \\
\hline Foo JY & Australia & 2013 & $\begin{array}{l}214 \text { twin and } 3942 \\
\text { singleton }\end{array}$ & SGA, The rates of preeclampsia & $\begin{array}{l}\text { The possibility of } \mathrm{PE} \text { in twin pregnancy with } \\
\text { chronic hypertension was higher than that in } \\
\text { singleton pregnancy }(\mathrm{P}<0.0 \mathrm{I}) \text {. The gestational } \\
\text { age of twin pregnancy with } \mathrm{PE} \text { was earlier }(\mathrm{P}< \\
0.00 \mathrm{I}) \text {, and SGA was more. }\end{array}$ & [56] \\
\hline Laine & Norway & 2019 & 16,174 twin & $\begin{array}{l}\text { The rate of gestational } \\
\text { hypertensive disorders }\end{array}$ & $\begin{array}{l}\text { The risk of preeclampsia in twin pregnancies } \\
\text { was higher than previously reported, } \\
\text { additionally, the prevalence of preeclampsia in } \\
\text { twin pregnancies was three to four times } \\
\text { higher than that of singleton pregnancies }\end{array}$ & [42] \\
\hline Savvidou & UK & 2001 & $\begin{array}{l}\text { I7I MC and } 495 \\
\text { DC }\end{array}$ & The incidence of pre-eclampsi & $\begin{array}{l}\text { No difference in the risk of preeclampsia } \\
\text { between monozygotic chorionic twins and } \\
\text { dizygotic chorionic twins }\end{array}$ & [48] \\
\hline
\end{tabular}

Abbreviations: DC, dichorionic; GDM, gestational diabetes mellitus; HDP, hypertensive disorders in pregnancy; MAP, mean arterial pressure; MVM, maternal vascular malperfusion; MC, monochorionic; MCDA, monochorionic diamniotic twin; PI, pulse index; PE, preeclampsia; SGA, small for gestational age.

ratio $<38$ was significantly shorter and the preterm birth rate was higher. ${ }^{84}$ The sflt1/PIGF ratio was 38 in $90 \%$ of women suspected or diagnosed with Preeclampsia, which is rather stable. ${ }^{85} \mathrm{~A}$ recent randomized control trial found that using preeclampsia measurement in the treatment of women with suspected Preeclampsia can significantly improve postpartum outcomes. ${ }^{86} \mathrm{~A}$ larger cohort study is needed to confirm whether twins and singletons are consistent with the same probability value in the prediction of preeclampsia needs.

Preeclampsia can currently be treated with a number of medications (eg methyldopa, hydralazine, magnesium sulfate). ${ }^{87}$ PreeclampsiaThe severity of the symptoms determines preeclampsia treatment. It is critical to consider timely delivery in clinical work in order to assess and reduce the incidence rate of maternal and perinatal diseases. The most important factors are gestational age, the progression of maternal disease, and the health of the fetus. Women with Preeclampsia should be delivered as soon as possible after 37 weeks of pregnancy, according to most national guidelines, ${ }^{88,89}$ and the risk of mothers after delivery can be significantly reduced. However, the best delivery time for women with late preterm Preeclampsia (34-37 weeks gestation) is unknown because the severity of maternal disease progression must be balanced against the importance of fetal management (including abnormal fetal heart rate requiring 
emergency delivery, worsening growth restriction, stillbirths, etc.). ${ }^{90}$ The current standard of care is to have an expectant treatment before 37 weeks of pregnancy. Serious complications could arise if the clinical situation changes, so the delivery should be scheduled ahead of time. On a global scale, these recommendations are still used by countries. ${ }^{91}$ Due to its unique complications, twin pregnancies in combination with a singleton strategy are ideal, based on the situation and analysis.

In the last decade, our understanding of the pathophysiology of Preeclampsia has advanced significantly. One of the fundamental mechanisms of maternal systemic vascular dysfunction is endothelial dysfunction caused by placental antiangiogenic factors. Imbalance is becoming more widely used in clinical practice to investigate clinical treatment options from the perspective of maternal angiogenesis. Preeclampsia is currently a special risk factor for future cardiovascular disease in women. Furthermore, hypertension, hyperlipidemia, and diabetes are the most closely monitored conditions. Women with a history of Preeclampsia are given lifestyle recommendations. However, it is still unclear how to improve these women's cardiovascular health. ${ }^{92}$ To further refine treatment strategies and programs, more research is needed to develop appropriate strategies for monitoring and intervening with these women and conducting differential treatment analyses of singletons and twins. The clinical treatment strategy of regulating angiogenesis imbalance is expected to lower the risk of complications and lengthen the gestational period. In addition, elucidating pathophysiology and developing accurate detection and prevention methods can help preeclampsia women reduce their risk of cardiovascular disease.

\section{Conclusion}

Preeclampsia risk is significantly higher in twin pregnancies than in singleton pregnancies. Its complications appear sooner, progress more quickly, and the condition becomes more serious. On the other hand, women with twin pregnancies are usually either not grouped with singleton pregnancies in the study or are excluded entirely. In today's obstetric clinical work, the management of these patients has presented a unique challenge. The major contradiction that obstetric staff will have to resolve in the future is to improve perinatal outcomes while simultaneously lowering the incidence rate and mortality of women around the world. The pregnancy process for twins is different from that of a singleton pregnancy, as is the pathophysiological process of Preeclampsia. The treatment of twin pregnancies must be separated from treatment guidance to improve the perinatal outcome of twin pregnancies and carry out accurate twin pregnancy management.

\section{Statement of Ethics}

This article does not contain any studies with human or animals performed by any of the authors.

\section{Author Contributions}

All authors contributed to data analysis, drafting or revising the article, have agreed on the journal to which the article will be submitted, gave final approval of the version to be published, and agree to be accountable for all aspects of the work.

\section{Funding}

This work was supported by the Natural Science Foundation of Liaoning Province (No. 2020-MS-03), the Science Foundation of Liaoning Education Department (FWZR2020012) and the 345 Talent Project of Shengjing hospital.

\section{Disclosure}

The authors declare no conflicts of interest in this work.

\section{References}

1. Wei J, Qi-Jun W, Zhang T-N, et al. Complications in multiple gestation pregnancy: a cross-sectional study of ten maternal-fetal medicine centers in China. Oncotarget. 2016;7(21):30797.

2. Grantz KL, Kawakita T, Lu Y-L, Newman R, Berghella V, Caughey A. SMFM SPECIAL STATEMent: state of the science on multifetal gestations: unique considerations and importance. Am $J$ Obstet Gynecol. 2019;221(2):B2-B12. doi:10.1016/j.ajog.2019.04.013

3. Narang K, Szymanski LM. Multiple gestations and hypertensive disorders of pregnancy: what do we know? Curr Hypertens Rep. 2021;23:1. doi:10.1007/s11906-020-01107-4

4. Stulberg DB, Jackson RA, Freedman LR. Referrals for services prohibited in Catholic health care facilities. Perspect Sex Reprod Health. 2016;48:111-117. doi:10.1363/48e10216

5. American College of Obstetricians and Gynecologists. Hypertension in pregnancy. Report of the American College of Obstetricians and Gynecologists' Task Force on Hypertension in Pregnancy. Obstet Gynecol. 2013;122(5):1122-1131. doi:10.1097/ 01.AOG.0000437382.03963.88

6. Cecil RL, Goldman L, Schafer AI. Goldman's Cecil Medicine (24th Ed). Philadelphia, PA: Elsevier Saunders; 2012.

7. Tranquilli AL, Landi B, Giannubilo SR, Sibai BM. Preeclampsia: no longer solely a pregnancy disease. Pregnancy Hypertens. 2012;2 (4):350-357. doi:10.1016/j.preghy.2012.05.006

8. Caritis S, Sibai B, Hauth J, et al. Low-dose aspirin to prevent preeclampsia in women at high risk. National Institute of Child Health and Human Development Network of Maternal-Fetal Medicine Units. $N$ Engl J Med. 1998;338(11):701-705. doi:10.1056/ NEJM199803123381101 
9. Bellamy L, Casas JP, Hingorani AD, Williams DJ. Preeclampsia and risk of cardiovascular disease and cancer in later life: systematic review and meta-analysis. BMJ. 2007;335(7627):974. doi:10.1136/ bmj.39335.385301.BE

10. Veerbeek JH, Hermes W, Breimer AY, et al. Cardiovascular disease risk factors after early-onset preeclampsia, late-onset preeclampsia, and pregnancy-induced hypertension. Hypertension. 2015;65 (3):600-606. doi:10.1161/HYPERTENSIONAHA.114.04850

11. Poon LC, Shennan A, Hyett JA, et al. The International Federation of Gynecology and Obstetrics (FIGO) initiative on pre- eclampsia: a pragmatic guide for first-trimester screening and prevention. Int J Gynaecol Obstet. 2019;145(Suppl 1):1-33. doi:10.1002/ ijgo. 12802

12. Robillard PY, Dekker G, Iacobelli S, Chaouat G. An essay of reflection: why does preeclampsia exist in humans, and why are there such huge geographical differences in epidemiology? J Reprod Immunol. 2016;114:44-47. doi:10.1016/j.jri.2015.07.001

13. Lisonkova S, Joseph KS. Incidence of preeclampsia: risk factors and outcomes associated with early-versus late-onset disease. $\mathrm{Am}$ $J$ Obstet Gynecol. 2013;209:544. e1-544.e12. doi:10.1016/j. ajog.2013.08.019

14. Rasmussen S, Irgens LM, Espinoza J. Maternal obesity and excess of fetal growth in preeclampsia. BJOG. 2014;121(11):1351-1357. doi:10.1111/1471-0528.12677

15. Ros HS, Cnattingius S, Lipworth L. Comparison of risk factors for preeclampsia and gestational hypertension in a population-based cohort study. Am J Epidemiol. 1998;147(11):1062-1070. doi:10.1093/oxfordjournals.aje.a009400

16. Li X, Tan H, Huang X, et al. Similarities and differences between the risk factors for gestational hypertension and preeclampsia: a population based cohort study in south China. Pregnancy Hypertens. 2016;6(1):66-71. doi:10.1016/j.preghy.2015.11.004

17. Krotz S, Fajardo J, Ghandi S, Patel A, Keith LG. Hypertensive disease in twins pregnancies: a review. Twins Res. 2002;5(1):8-14. doi:10.1375/twin.5.1.8

18. Francisco C, Wright D, Benkö Z, Syngelaki A, Nicolaides KH. Hidden high rate of preeclampsia in twins compared to singleton pregnancies. Ultrasound Obstet Gynecol. 2017;50(1):88-92. doi: $10.1002 /$ uog. 17470

19. Wen SW, Demissie K, Yang Q, Walker MC. Maternal morbidity and obstetric complications in triplet pregnancies and quadruplet and higher-order multiple pregnancies. Am J Obstet Gynecol. 2004;191 (1):254-258. doi:10.1016/j.ajog.2003.12.003

20. Levine RJ, Maynard SE, Qian C, et al. Circulating angiogenic factors and the risk of Preeclampsia. N Engl J Med. 2004;350(7):672-683. doi:10.1056/NEJMoa031884

21. Smith-Levitin M, Kowalik A, Birnholz J, et al. Selective reduction of multifetal pregnancies to twins improves outcome over nonreduced triplet gestations. Am J Obstet Gynecol. 1996;175:878-882. doi:10.1016/S0002-9378(96)80017-2

22. Bschier F, Beinder E. Temporary resolution of preeclamptic symptoms after intrauterine death of one twins. Hypertens Pregnancy. 2005;24:313-317. doi:10.1080/10641950500281100

23. Okby R, Harlev A, Sacks KN, Sergienko R, Sheiner E. Preeclampsia acts differently in in vitro fertilization versus spontaneous twins. Arch Gynecol Obstet. 2018;297(3):653-658. A retrospective population based study investigating the incidence of Preeclampsia in IVF twins pregnancies; with concluding that it is more common than in spontaneous twins pregnancies. doi:10.1007/s00404-017-4635-y

24. Sites CK, Wilson D, Barsky M, et al. Embryo cryopreservation and preeclampsia risk. Fertil Steril. 2017;108(5):784-790. doi:10.1016/j. fertnstert.2017.08.035

25. Schroeder BM. ACOG practice bulletin on diagnosing and managing preeclampsia and eclampsia. American College of Obstetricians and Gynecologists. Am Fam Physician. 2002;66(2):330-331.
26. Zhang HN, Xu QQ, Thakur A, et al. Endothelial dysfunction in diabetes and hypertension: role of microRNAs and long non-coding RNAs. Life Sci. 2018;213:258-268. doi:10.1016/j.lfs.2018.10.028

27. Maynard SE, Min JY, Merchan J, et al. Excess placental soluble fms-like tyrosine kinase 1 (sFlt1) may contribute to endothelial dysfunction, hypertension, and proteinuria in preeclampsia. $J$ Clin Investig. 2003;111:649-658. doi:10.1172/JCI17189

28. Venkatesha S, Toporsian M, Lam C, et al. Soluble endoglin contributes to the pathogenesis of preeclampsia. Nat Med. 2006;12:642-649. doi:10.1038/nm1429

29. Levine RJ, Lam C, Qian C, et al. Soluble endoglin andother circulating antiangiogenic factors in preeclampsia. $N$ Engl $J$ Med. 2006;355:992-1005. doi:10.1056/NEJMoa055352

30. McGinnis R, Steinthorsdottir V, Williams NO, et al. Variants in the fetal genome near FLT1 are associated with risk of preeclampsia. Nat Genet. 2017;49:1255-1260. doi:10.1038/ng.3895

31. Gray KJ, Saxena R, Karumanchi SA. Genetic predisposition to preeclampsia is conferred by fetal DNA variants near FLT1, a gene involved in the regulation of angiogenesis. Am J Obstet Gynecol. 2018;218:211-218. doi:10.1016/j.ajog.2017.11.562

32. Bdolah Y, Palomaki GE, Yaron Y, et al. Circulating angiogenic proteins in trisomy 13. Am J Obstet Gynecol. 2006;194:239-245. doi:10.1016/j.ajog.2005.06.031

33. Kendall RL, Thomas KA. Inhibition of vascular endothelial cell growth factor activity by an endogenously encoded soluble receptor. Proc Natl Acad Sci USA. 1993;90:10705-10709. doi:10.1073/pnas.90.22.10705

34. Dekker GA, Sibai BM. Etiology and pathogenesis of preeclampsia: current concepts. Am J Obstet Gynecol. 1998;179:1359-1375. doi:10.1016/S0002-9378(98)70160-7

35. Burton GJ. Pre-eclampsia: pathophysiology and clinical implications. BMJ. 2019;366:12381. doi:10.1136/bmj.12381

36. Yu W, Gao W, Rong D, Wu Z, Khalil RA. Molecular determinants of microvascular dysfunction in hypertensive pregnancy and preeclampsia. Microcirculation. 2019;26:e12508. doi:10.1111/micc.12508

37. Chazara O, Xiong S, Moffett A. Maternal KIR and fetal HLA-C: a fine balance. J Leukoc Biol. 2011;90:703-716. doi:10.1189/ jlb.0511227

38. Hiby SE, Apps R, Sharkey AM, et al. Maternal activating KIRs protect against human reproductive failure mediated by fetal HLA-C2. J Clin Invest. 2010;120(11):4102-4110. doi:10.1172/ JCI43998

39. Robillard PY, Dekker GA, Hulsey TC. Revisiting the epidemiological standard of preeclampsia: primigravidity or primipaternity? Eur J Obstet Gynecol Reprod Biol. 1999;84:37-41. doi:10.1016/S03012115(98)00250-4

40. Deen ME, Ruurda LG, Wang J, Dekker GA. Risk factors for preeclampsia in multiparous women: primipaternityversus the birth interval hypothesis. J Matern Fetal Neonatal Med. 2006;19:79-84. doi:10.1080/14767050500361653

41. Saito S, Sakai M. Th1/Th2 balance in preeclampsia. J Reprod Immunol. 2003;59:161-173. doi:10.1016/S0165-0378(03)00045-7

42. Sasaki Y, Darmochwal-Kolarz D, Suzuki D, et al. Proportion of peripheral blood and decidual $\mathrm{CD} 4(+) \mathrm{CD} 25$ (bright) regulatory $\mathrm{T}$ cells in preeclampsia. Clin Exp Immunol. 2007;149:139-145. doi:10.1111/j.1365-2249.2007.03397.x

43. Derzsy Z, Prohaszka Z, Rigo JJ, Fust G, Molvarec A. Activation of the complement system in normal pregnancy and preeclampsia. Mol Immunol. 2010;47(7-8):1500-1506. doi:10.1016/j. molimm.2010.01.021

44. Jean FR, Richard MB, Sherry DF. The complement system and preeclampsia. Curr Hypertens Rep. 2017;19:2-12. doi:10.1007/ s11906-017-0704-7

45. Lynch AM, Murphy JR, Byers T, et al. Alternative complement pathway activation fragment $\mathrm{Bb}$ in early pregnancy as a predictor of preeclampsia. Am J Obstet Gynecol. 2008;198:385. doi:10.1016/j. ajog.2007.10.793 
46. Sones JL, Merriam AA, Seffens A, et al. Angiogenic factor imbalance precedes complement deposition in placentae of the $\mathrm{BPH} / 5$ model of preeclampsia. FASEB J. 2018;32(5):2574-2586. doi:10.1096/fj.201701008R

47. Vaught AJ, Braunstein EM, Jasem J, et al. Germline mutations in the alternative pathway of complement predispose to HELLP syndrome. JCI Insight. 2018;3(6):99128. doi:10.1172/jci.insight.99128

48. Vaught AJ, Gavriilaki E, Hueppchen N, et al. Direct evidence of complement activation in HELLP syndrome: alink to atypical hemolytic uremic syndrome. Exp Hematol. 2016;44:390-398. doi:10.1016/ j.exphem.2016.01.005

49. Girardi G, Yarilin D, Thurman JM, Holers VM, Salmon JE. Complement activation induces dysregulation of angiogenic factors and causes fetal rejection and growth restriction. J Exp Med. 2006;203:2165-2175. doi:10.1084/jem.20061022

50. Lucovnik M, Blickstein I, Lasic M, et al. Hypertensive disorders during monozygotic and dizygotic twins gestations: a population-based study. Hypertens Pregnancy. 2016;35:1-6. A population based study evaluating the impact of twins zygosity (monozygotic vs dizygotic) on preeclampsia risk and outcomes. The study concludes no difference based on zygosity. doi:10.1080/ 10641955.2016.1197936

51. Rantakallio JSS, Nevalainen JE, West SI, et al. Association of self-reported polycystic ovary syndrome, obesity, and weight gain from adolescence to adulthood with hypertensive disorders of pregnancy: a community-based approach. Hypertension. 2021;77 (3):1010-1019. doi:10.1161/HYPERTENSIONAHA.120.15702

52. Mustafa R, Ahmed S, Gupta A, Venuto RC. A comprehensive review of hypertension in pregnancy. J Pregnancy. 2012;2012:105918. doi: $10.1155 / 2012 / 105918$

53. Horikoshi M, Beaumont RN, Day FR, et al. Genome-wide associations for birth weight and correlations with adult disease. Nature. 2016;538(7624):248-252. doi:10.1038/nature19806

54. Laine K, Murzakanova G, Sole KB, Pay AD, Heradstveit S, Räisänen S. Prevalence and risk of preeclampsia and gestational hypertension in twins pregnancies: a population-based register study. BMJ Open. 2019;9(7):e029908. doi:10.1136/bmjopen-2019-029908

55. Sibai BM, Hauth J, Caritis S, et al. Hypertensive disorders in twins versus singleton gestations. National Institute of Child Health and Human Development Network of Maternal-Fetal Medicine Units. Am J Obstet Gynecol. 2000;182:938-942. doi:10.1016/s0002-9378(00)70350-4

56. Bartsch E, Medcalf KE, Park AL, et al. Clinical risk factors for preeclampsia determined in early pregnancy: systematic review and meta-analysis of large cohort studies. BMJ. 2016;353:i1753. doi:10.1136/bmj.i1753

57. Petersen SH, Bergh C, Gissler $M$, et al. Time trends in placenta-mediated pregnancy complications after assisted reproductive technology in the Nordic countries. Am J Obstet Gynecol. 2020;223(2). doi:10.1016/j.ajog.2020.02.030

58. Henry DE, McElrath TF, Smith NA. Preterm severe preeclampsia in singleton and twin pregnancies. J Perinatol. 2013;33(2). doi:10.1038/ jp. 2012.74

59. Bartnik P, Kosinska-Kaczynska K, Kacperczyk J, et al. Twins chorionicity and the risk of hypertensive disorders: gestational hypertension and Pre-eclampsia. Twins Res Hum Genet. 2016;19:377-382. doi:10.1017/thg.2016.17

60. Sparks TN, Cheng YW, Phan N, et al. Does risk of preeclampsia differ by twins chorionicity? J Matern Fetal Neonatal Med. 2013;26:1273-1277. doi:10.3109/14767058.2013.777701

61. Savvidou MD, Karanastasi E, Skentou C, et al. Twins chorionicity and preeclampsia. Ultrasound Obstet Gynecol. 2001;18:228-231. doi:10.1046/j.0960-7692.2001.00470

62. Hiersch L, Berger H, Okby R, Ray JG, Geary M, McDonald SD. Gestational diabetes mellitus is associated with adverse outcomes in twin pregnancies. Am J Obstet Gynecol. 2019;220(1):102.e1-102.e8. doi:10.1016/j.ajog.2018.10.027
63. Svirsky R, Yagel S, Ben-Ami I, Cuckle H, Klug E, Maymon R. First trimester markers of preeclampsia in twins: maternal mean arterial pressure and uterine artery Doppler pulsatility index. Prenat Diagn. 2014;34:956-960. doi:10.1002/pd.4402

64. Chen Q, Izumi A, Minakami H, Sato I. Comparative changes in uterine 5rtery blood flow waveforms in singleton and twin pregnancies. Gynecol Obstet Invest. 1998;45:165-169. doi:10.1159/000009948

65. Mourad M, Too G, Gyamfi-Bannerman C, Zork N. Hypertensive disorders of pregnancy in twin gestations complicated by gestational diabetes. J Matern Fetal Neonatal Med. 2021;34(5):720-724. doi:10.1080/14767058.2019.1614160

66. Mor N, Machtinger R, Yinon Y, et al. Outcome of two sequential singleton pregnancies and twin pregnancies among primiparous women at advanced age undergoing IVF. Arch Gynecol Obstet. 2020;302(5):1113-1119. doi:10.1007/s00404-020-05700-5

67. Aviram A, Giltvedt MK, Sherman C, et al. The role of placental malperfusion in the pathogenesis of preeclampsia in dichorionic twin and singleton pregnancies. Placenta. 2018;70:41-49. doi:10.1016/j. placenta.2018.09.002

68. Foo JY, Mangos G, Brown M. OS096. Characteristics of hypertensive disorders in twin versus singleton pregnancies. Pregnancy Hypertens. 2012;2(3):230-231. doi:10.1016/j.preghy.2012.04.097

69. Foo JY, Mangos GJ, Brown MA. Characteristics of hypertensive disorders in twin versus singleton pregnancies. Pregnancy Hypertens. 2013;3(1):3-9. doi:10.1016/j.preghy.2012.05.005

70. Connolly KA, Factor SH, Getrajdman CS, Bigelow CA, Weintraub AS, Stone JL. Maternal clinical disease characteristics and maternal and neonatal outcomes in twin and singleton pregnancies with severe preeclampsia. Eur J Obstet Gynecol Reprod Biol. 2016;201:36-41. doi:10.1016/j.ejogrb.2015.11.031

71. Myatt L, Roberts JM. Preeclampsia: syndrome or disease? Curr Hypertens Rep. 2015;17(11):83. doi:10.1007/s11906-015-0595-4

72. English FA, Kenny LC, McCarthy FP. Risk factors and effective management of preeclampsia. Integr Blood Press Control. 2015;8:7-12. doi:10.2147/IBPC.S50641

73. Sibai B, Dekker G, Kupferminc M. Pre-eclampsia. Lancet. 2005;365:785-799. doi:10.1016/S0140-6736(05)71003-5

74. Duley L, Henderson-Smart DJ, Meher S, King JF. Antiplatelet agents for preventing preeclampsia and its complications. Cochrane Database Syst Rev. 2007;2:CD004659.

75. CLASP (Collaborative Low-dose Aspirin Study in Pregnancy) Collaborative Group. CLASP: a randomised trial of low-dose aspirin for the prevention and treatment of preeclampsia among 9364 pregnant women. Lancet. 1994;343:619-629. doi:10.1016/S01406736(94)92633-6

76. Sibai BM, Caritis SN, Thom E, Shaw K, McNellis D; National Institute of Child Health and Human Developmental Maternal-Fetal Medicine Network. Low-dose aspirin in nulliparous women: safety of continuous epidural block and correlation between bleeding time and maternal-neonatal bleeding complications. Am J Obstet Gynecol. 1995;172:1553-1557. doi:10.1016/0002-9378(95)90495-6

77. World Health Organization. WHO recommendations for prevention and treatment of Pre-eclampsia and eclampsia; 2011. Available from: http://whqlibdoc.who.int/publications/2011/9789241548335_eng.pdf. Accessed October 5, 2015.

78. Panagodage S, Yong HEJ, Da Silva Costa F. Low-dose acetylsalicylic acid treatment modulates the production of cytokines and improves trophoblast function in an in vitro model of early-onset preeclampsia. Am J Pathol. 2016;186:3217-3224. doi:10.1016/j.ajpath.2016.08.010

79. Goodnight W, Newman R; Society of Maternal-Fetal Medicine. Optimal nutrition for improved twins pregnancy outcome. Obstet Gynecol. 2009;114:1121-1134. doi:10.1097/AOG.0b013e3181bb14c8

80. Rana S, Powe CE, Salahuddin S, et al. Angiogenic factors and the risk of adverse outcomes in women with suspected preeclampsia. Circulation. 2012;125:911-919. doi:10.1161/CIRCULATIONAHA. 111.054361 
81. Chaiworapongsa T, Romero R, Savasan ZA, et al. Maternal plasma concentrations of angiogenic/antiangiogenic factors are of prognostic value in patients presenting to the obstetrical triage area with the suspicion of preeclampsia. J Matern Fetal Neonatal Med. 2011;24:1187-1207. doi:10.3109/14767058.2011.589932

82. Zeisler H, Llurba E, Chantraine F, et al. Predictive value of the sFlt-1: plGFratio in women with suspected preeclampsia. $N$ Engl J Med. 2016;374:13-22. doi:10.1056/NEJMoa1414838

83. Rana S, Schnettler WT, Powe C, et al. Clinical characterization and outcomes of preeclampsia with normal angiogenic profile. Hypertens Pregnancy. 2013;32:189-201. doi:10.3109/10641955.2013.784788

84. Zeisler H, Llurba E, Chantraine F, et al. Soluble fms-like tyrosine kinase-1-to-placental growth factor ratio and time to delivery in women with suspected preeclampsia. Obstet Gynecol. 2016;128:261-269. doi:10.1097/AOG.0000000000001525

85. Saleh L, van den Meiracker AH, Geensen R, et al. Soluble fms-like tyrosine kinase-1 and placental growth factor kinetics during and after pregnancy in women with suspected or confirmed preeclampsia. Ultrasound Obstet Gynecol. 2018;51:751-757. doi:10.1002/uog.17547

86. Duhig KE, Myers J, Seed PT, et al.; PARROT trial group. Placental growth factor testing to assess women with suspected preeclampsia: a multicentre, pragmatic, stepped-wedge cluster-randomised controlled trial. Lancet. 2019;393:1807-1818. doi:10.1016/S01406736(18)33212-4

87. McCoy S, Baldwin K. Pharmacotherapeutic options for the treatment of preeclampsia. Am J Health Syst Pharm. 2009;66:337-344. doi:10.2146/ajhp080104
88. Gyamfi-Bannerman C, Gantt AB, Miller RS. ACOG Committee Opinion No 764: medically indicated late-preterm and early-term deliveries. Obstet Gynecol. 2019;133:e151-e155. doi:10.1097/ AOG.0000000000003083

89. NICE. Hypertension in pregnancy: the management of hypertensive disorders during pregnancy. London: National Institute for Health and Care Excellence; 2010.

90. Koopmans CM, Bijlenga D, Groen H. Induction of labour versus expectant monitoring for gestational hypertension or mild preeclampsia after 36 weeks' gestation (HYPITAT): a multicentre, open-label randomised controlled trial. Lancet. 2009;374:979-988. doi:10.1016/ S0140-6736(09)60736-4

91. Brown MA, Magee LA, Kenny LC. The hypertensive disorders of pregnancy: ISSHP classification, diagnosis \& management recommendations for international practice. Pregnancy Hypertens. 2018;13:291-310. doi:10.1016/j.preghy.2018.05.004

92. Gamble DT, Brikinns B, Myint PK, Bhattacharya S. Hypertensive disorders of pregnancy and subsequent cardiovascular disease: current national and international guidelines and the need for future research. Front Cardiovasc Med. 2019;6:55. doi:10.3389/ fcvm.2019.00055
Risk Management and Healthcare Policy

\section{Publish your work in this journal}

Risk Management and Healthcare Policy is an international, peerreviewed, open access journal focusing on all aspects of public health, policy, and preventative measures to promote good health and improve morbidity and mortality in the population. The journal welcomes submitted papers covering original research, basic science, clinical \& epidemiological studies, reviews and evaluations,

\section{Dovepress}

guidelines, expert opinion and commentary, case reports and extended reports. The manuscript management system is completely online and includes a very quick and fair peer-review system, which is all easy to use. Visit http://www.dovepress.com/testimonials.php to read real quotes from published authors. 